\title{
Perceptions in a Pedagogical Intervention in Technology Education in Four Schools of Bogotá and Cundinamarca
}

\author{
Laura A. Díaz, Fredy A. Olarte, Ligia Ochoa \\ Universidad Nacional de Colombia, Colombia
}

\begin{abstract}
Appropriation and innovation of technology and its integration in the school curriculum are popular topics in Colombia because they have produced significant changes in the teaching - learning process. The Ministry of National Education proposed in 2008 a guideline for technology education [1]. This paper seeks to explain the social representations of teachers and students participating in the project "Regional Innovation Educational Centers - Center area" because it is essential to design tools that serve as a guide for teaching - learning of students in the technology area. It also presents some approaches about the pedagogical intervention developed and the methodology used to establish the social representations, in order to propose alternatives to improve the quality of the technology area in Colombia.
\end{abstract}

\section{Introduction}

In Colombia, the Ministry of National Education includes the study of technology as a subject that should be taught in primary and secondary education. For teaching this subject in the country, it proposed the "Guide Series No. 30. To be competent in technology: a need for development", a document that presents the general guidelines for education in technology [1].

Probably because it is a relatively new subject, compared with others, teachers do not use the technology area guidelines to develop their classes. Another major shortcoming is the fact that about $70 \%$ of teachers in this area have not been trained in technology and that the orientation in secondary and high school education is mainly technical [2]. Therefore, each institution may have a different approach in the area, according to the teachers training, the institution emphasis and its resources.

Another problem for technology education in the country is that, in some cases, programs financed by government agencies are not evaluated in terms of participant's perceptions and this makes difficult to suggest changes that would eventually improve the pedagogical intervention implementation.

The Guide Series No. 30 has been taken as a basic document for the program that seeks design, implement and evaluate strategies for the development of technological skills of students, through the creation and the educational use of ICT tools. Whereon the present study was based to determine the participants social representations. Although the Guide Series No. 30 aims to serve as a guide for teaching in technology, it has failed to be a unified approach to guide teachers in their work, probably because the guidelines are less clear and precise compared with another subject's guidelines.

\section{Technology Education}

Through the study of technology, people will become more enterprising, innovative, skillful, knowledgeable, adaptable, critically and resourcefully to challenges, generate and apply new ideas, work cooperatively as a team and find innovative solutions to community needs [3]. Technology education develops students' capabilities with the processes and should involve a reasonable balance of theoretical and practical information that reinforce conceptual understanding, by increasing on student interest in addressing real-world situations and getting involved with creating, constructing, discovering and problem-solving [4].

The book "Technology Education for Teachers" presents a description of four basic domains of technology, taken from the

American philosopher Carl Mitcham. The structure he proposes is based on four different ways of conceptualizing technology: as a collection of artefacts, as a knowledge domain or discipline, as a set of activities and as a field of human and social values [5].

The first domain is technology as artefacts, which are in fact the outcome of technology, but we often associate them with technology itself. Artefacts are the most direct way we get in contact with technology. The second, is technology as knowledge, because technology is something you can learn or study although technological knowledge differs from scientific knowledge. The third domain consists in the activities or processes that characterize the technology, because all that has been written about technological processes is about design. The fourth way of thinking of technology is as values, where students develop their own normative ideas about how technology should function in society and their 
own personal lives. Also when technology makes them value the human life [5].

A technology education programme provides a motivating and attractive stimulus to a learning environment in which students can develop skills that will increase their abilities to solve practical problems, make decisions and interpret the technology impacts on society [4]. Different countries have worked in the technology area and use different terms to describe technology education. Also they present the way they have developed educational programs and national curriculums [5].

Rasinen [3] presents an investigation developed in six countries: Australia, England, France, The Netherlands, Sweden, and the United States, in which technology education programs have developed rapidly over the past ten years. The aim of this study was to find information that could be used in establishing a theoretical basis for planning the technology education curriculum [4].

The Latin American Network of Portals aims to become a world leader in educational content management through communication projects and experiences developed in the community. That is why since its creation and in a relatively short period it has made changes in the educational scenario with regard to the technology area, including computers in the classroom, increasing the equipment acquisition and improving the connectivity of educational institutions through national infrastructure investment plans [6].

In Colombia researchers have not worked extensively in the field of technology education. Within the current studies may be mentioned the document "Education and Society: Reflections and Case Studies in Ibero-América", which refers to competences in technology through differentiation between two conceptual levels: e-skills and digital literacies. The document' aim is to promote the use and appropriation of new ICT technologies [7].

Despite this, in Colombia many schools have low possibilities of access to technological resources, especially in rural areas where there is a limited government action in the educative institutions. Additionally, some conditions such as limited infrastructure generate little or no influence of ICT and leave teachers in technological backwardness. But it is not a difficulty exclusive of teachers, because although for students, technology gives possibilities of social ascension, they do not have access to it.

\section{Social Representations}

The main interest of this work focuses on the perceptions of technology education of teachers and students in the tenth and eleventh grades in four schools of Bogota and Cundinamarca. The lead author who has studied perceptions is Serge
Moscovici, with his theory of social representations, which designates the broad social beliefs about some aspects of society. These representations are presented in different ways: categories for classifying the circumstances, images, phenomena, individuals, theories and referral systems [8].

Durkheim is considered the precursor of the representation notion; he appointed "collective representations" the social phenomenon whereby different individual representations are constructed. For the author collective representations are a kind of social mental productions endowed with fixing and objectivity. Because they seem to possess the same objectivity of natural things and are imposed imperatively to the people [9].

Moscovici says that collective representations have led to social representations because while the first one is an explanatory term the second one is a way to create the reality and the common sense [10].

To study the social representation of an object allows knowing the constitution of thought processes, through which people construct and reconstruct reality and social identity and their "world view" and with which act and take positions on different social objects [9].

For Moscovici four constituent elements rise of social representations: the image connected to what I "see"; information related to what I "know"; the views referring to what I "think" and the attitudes related to what I "feel" [8]. These categories presented by the author will be the guide for the analysis and categorization of the perceptions identified in this investigation.

\section{Author name(s) and affiliation(s)}

To fulfill the investigation purpose, a study of mixed cut was posed combining quantitative and qualitative data. These data were obtained in three stages: at the beginning, during and after the pedagogical intervention to know the participants' perceptions [11]. According to Abric (2001), the social representations study raises two methodological problems, on the one hand the collection of representations and on the other the analysis of the data obtained. Therefore, the choice of the methodology is determined by empirical considerations as the nature of the object studied, the type of population, impositions of the situation, among others; but also by the theoretical system that sustains and justifies the research [12]. Meanwhile, Coulon [13] argue that the analysis of social representations privileges the speeches analysis, thus the open interview and questionnaire techniques are used more frequently. In accordance with the above and with the results obtained from the review of the background, they will also be the data collection methods that are mainly used in this investigation [13]. 
The participants sample were teachers in the technology area and their students in the tenth or eleventh grade of four institutions in Bogotá and Cundinamarca belonging to CIER Center: Pedagogical Institute Arturo Ramírez Montufar (Bogotá), Educational Institution Santa Ana (Soacha) Educational Institution Diego Gomez Mena (Tabio) and Departmental Educational Institution Bagazal (Villeta). These schools were selected through a call made by the Ministry of National Education.

Before the pedagogical intervention data collection it was performed in two stages: the first of them was a working session in which were made three focus groups of teachers, in order to converse more intimate, flexible and open manner. This technique was developed to discuss relevant information and delve deeper into the respondents' answers second part, was made in the mentioned schools through visits that were conducted group interviews with students, such meetings were directed toward understanding the perspectives of the informants about their lives, experiences or situations, as they expressed in their own words [14].

In the stage of during, data collection was performed in two moments: in the first, closed surveys were made and focus groups were formed to collect the students' views on the matter. The surveys had 15 questions and could be answered according to the Likert scale from 1 to 5 , where 1 corresponded to "it does not describe me" and 5 to "it fully describes me". On the other hand, the two focus groups were made in each institution approximately with five students chosen randomly [10].

In the second moment, two focus groups were conducted in order to investigate about the way in which the strategy had been implemented so far [10] and to understand the perceptions of technology teachers.

Finally, about a month after the end of the pedagogical intervention, were also made focus groups with teachers and students seeking to focus on the perceptions of the pedagogical intervention already completed. In addition before doing focus groups with students were asked to fill again the same survey had been conducted during the operation. With the design and implementation of data collection instruments mentioned above it was possible to collect valuable information regarding the implementation and monitoring process with each school.

To perform the analysis of the data were transcribed focus groups, were tabulated the students' surveys and were classified the obtained data according to the established categories. In the surveys' analysis it was decided to remove items 4 and 14 because were considered ambiguous for students, their data are not included in the data analysis, but remained in the format until the end.
The categories were established inductively "I know", "what I think" and "I feel", from the analysis of Moscovici texts. However, due to the perceived flexibility between one and other category, it is not possible to say that some of the data as classified in one of them are not closely related to another. Therefore preset categories as Moscovici theory are a guide to analyze the data of this work but it is recognized that allow some flexibility in categorizing so they are not absolute and in another study the information may be classified so different.

Table 1. Categories of inductive and deductive reasoning

\begin{tabular}{|c|c|c|}
\hline $\begin{array}{l}\text { Inductive } \\
\text { Reasoning }\end{array}$ & $\begin{array}{l}\text { Deductive } \\
\text { Reasoning }\end{array}$ & \\
\hline \multirow{2}{*}{$\begin{array}{l}\text { "What } \\
\text { know" }\end{array}$} & Evaluation & \\
\hline & $\begin{array}{l}\text { Infrastructure } \\
\text { resources }\end{array}$ & $\mathrm{y}$ \\
\hline \multirow[t]{2}{*}{ "What I think" } & $\begin{array}{l}\text { Knowledge } \\
\text { construction }\end{array}$ & \\
\hline & Content & \\
\hline \multirow[t]{2}{*}{ "What I feel" } & Methodology & \\
\hline & Team work & \\
\hline
\end{tabular}

Also during the analysis of focus groups, were emerged deductive categories that allowed made an order based on the behavior of information in the fieldwork. Hence the variation about Moscovici categories worked with in methodological and analytical application of this research. As we can see in Table 1, each inductive deductive category has two emerge; however inductive absent the analytical unit "what I see". This unit, "what I see" has not addressed by considering the image a polysemic element that goes beyond the interests of this research. That is why the image will not be focus of this study; however, it may be a line of inquiry to follow.

Taking up the formulation of Table 1, during the analysis of focus group decisions among which it was considered that "what I know" or the information aimed at the assessment the infrastructure and the resources because they are issues that both teachers and students handled were taken in their daily lives; "what I think" or the opinions to the construction of knowledge and content because it is what they thought of the changes that were happening with the pedagogical intervention and finally, "what I feel" or the attitudes have to do with the methodology and teamwork that relate to the way in which participants pledged the class.

Therefore the data analyzed in this work were organized by instrument and by participant, it means, it presented each of the instruments that were used to collect data and the participants (students and 
teachers) of each school. Additionally, they were divided by three stages in which were collected: before, during and after.

\section{Results}

The results of the study were organized in three moments: before, during and after the pedagogical intervention:

\subsection{Before}

Results students' interviews The results of students' interviews are organized according to the questions asked. This paper contains two examples of questions with answers.

How is the technology and informatics class?

In a school students said that technology class involves drafting documents in Microsoft Word ${ }^{\circledR}$ through a document containing the guidelines to build them. In another institution during each session, students work in pairs developing a guide which is related with the use of programs like Visual Basic $\AA$, SketchUp®, Flash $₫$, Power Point $₫$, Photoshop®, programming languages, among others. The evaluation of technology and informatics class is based on the results of the development of the guides and the oral presentations.

Students also said that generally the class was developed through the use of the Office package, internet and computers with programs like Microsoft Word $®$, Cmap Tools $₫$, Photoshop $₫$ and Movie Maker®. Although it is difficult because sometimes the computers are outdated or damaged. Also they developed guides, made conceptual maps and PowerPoint ${ }^{\circledR}$ or Prezi ${ }^{\circledR}$ presentations.

What you do not like of the technology and informatics class?

In one of the institutions they said it is a routine class because they always develop guides. In another, they consider that computers weren't available for enough time and the tools that teachers taught were very limited, they only worked with programs of the Office package. Generally they did not have access to internet for connectivity problems and therefore they cannot take advantage of the computers.

Finally, they claim that there are not enough computers and they do not have the correct programs, and sometimes the class becomes monotonous and they would like to learn to program. Also, factors such as the lack of collaboration and participation of peers impede an appropriate atmosphere for the class.

Teachers' focus groups

The results of teachers' focus groups were organized according to the questions asked. This paper contains two examples of questions with answers.
How is your technology and informatics class?

In many cases they made the clarification that although the subject was called "Technology and informatics" was computer class only. Usually the class was characterized by search, investigate, create and innovate. Also they seek to integrate science and technology through a fair and with other subjects through the development of transversal projects.

In regard to the structure of the class, they made an introduction, takes into account the prior knowledge, encourage participation, they ask students to research on the subject and try to complete a work that in some cases developed through projects or with help from other educational institutions and evaluate theoretically or practice.

Do you know the Guide Series No. 30 proposed for the Ministry of National Education?

Some teachers said they did not know and they have heard others mention but have not read it. On the other hand, those who have worked with her claim that although they have made some things is a difficult material to contextualize because it lacks of clarity, requests unattainable things, some proposals are not very logical, there are very complex skills or require very high level of knowledge by the students.

\subsection{During}

Students' surveys and focus groups

The student surveys results were organized by institutions and by the categories stated above. Also, some interventions of the students in the focus groups supported the polls' results.

"What I know"

The first category is about the information; the students talked about the evaluation and the resources in their institutions. They consider the use given to resources within the class; allow them to perform well in the subject of technology and computing.

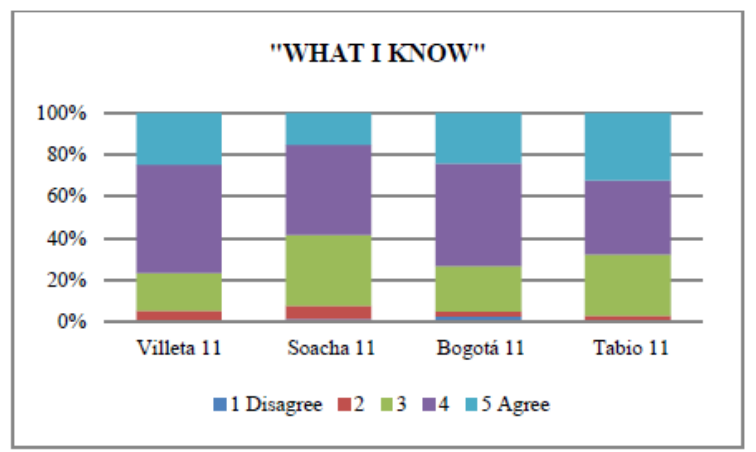

Figure 1. "What I know" during the pedagogical intervention

The Figure 1 presents the results obtained in the surveys for the questions 11 for each school. The corresponding colors to the levels assessed in the 
Likert scale are located at the bottom of the image, where 1 is disagree and 5 is agree.

E12: "What is needed are things to improve, more and faster computers; without virus, because you cannot bring your memory. There is not internet; the computers have no preventive maintenance. Also is required more space in the classroom" (Student, first focus group).

"What I think"

The second category is about the opinions; the students talked about the knowledge construction

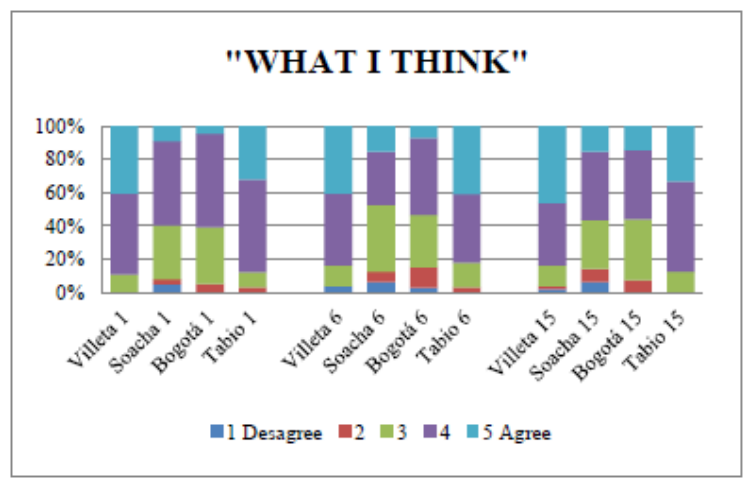

and the contents of the technology area. They consider the methodology and the topic of the class help them to solve problems of the daily life.

Figure 2. "What I think" during the pedagogical intervention.

The Figure 2 corresponds to the results obtained in the surveys for the questions 1,6 and 15 located on each school. The corresponding colors to the levels assessed in the Likert scale are located at the bottom of the image.

E15: "Yes, of course, it's posed a problem and tries to fix it because it is typical, because you in your everyday life you are going to present many problems, and therefore it could be helpful". (Student, first focus group).

"What I feel"

The third category is about the attitudes; the students talk about the methodology and teamwork. They said that work with the current methodology has advantages and they like it.

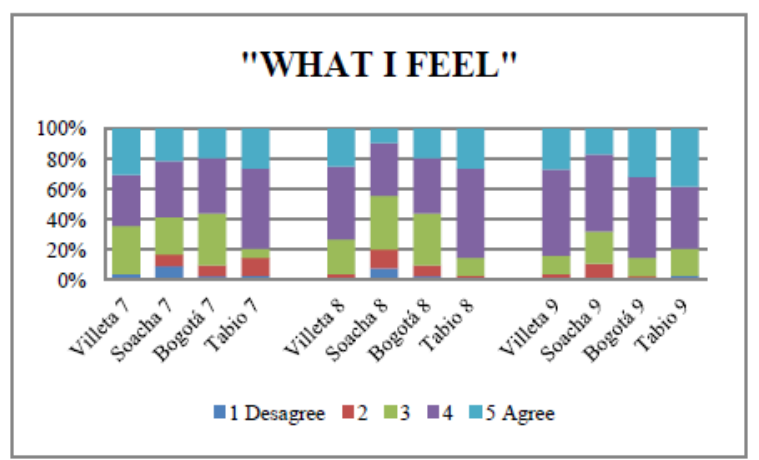

Figure 3. "What I feel" during the pedagogical intervention
The Figure 3 corresponds to the results obtained in the surveys for the questions 7,8 and 9 located on each school. The corresponding colors to the levels assessed in the Likert scale are located at the bottom of the image.

E12: "Well, as for myself, I do like the content, in general I like it" (Student, second focus group).

E11: "¡Ehh! Perhaps, they like the class; we like the subject, technology and learn about it" (Student, second focus group).

E2: "Reach agreements, work as a group, because before we only used the computer, and do our things but now it's like working in groups" (Student, first focus group).

Teachers' focus group

"What I know"

Teachers mentioned that the main difficulty they had in the project development was the number of students who were in the classroom. Also they said that has been complicated to assess individual learning because most of the work was done in groups. And they are not sure if a given student is learning or not.

T1: "The difficulties I have had are: logistics, overcrowding and lack of time; I think that PBL requires working with a few students" (Teacher, first focus group).

T1: "But to truly assess each student, that is the problem that I have because, you can evaluate the group but not individualize each student" (Teacher, first focus group).

"What I think"

Teachers said they had a good relationship with their students during the project. Also, teachers mentioned the motivation for the knowledge construction is really important.

T3: "I emphasized on the motivation that I can give to the students to research and to be creative. It is one of the few areas in the institutions' the curriculum that gives the teacher, the opportunity to focus and motivate the child to the knowledge and explore their ideas" (Teacher, second focus group).

T4: "The idea that you always has is that topic give to the students a love for learning and you always tries to make an initial activity that involves them and lead them to understand through previous knowledge" (Teacher, first focus group).

"What I feel"

The teachers felt that they saw the strategy as something new and they liked the project based learning.

T3: "Well, look to the mere fact that we already have a new strategy, that it is new, at least for those who did not work for projects" (Teacher, first focus group). 


\subsection{Main text}

Students' surveys and focus groups

The student surveys results were organized in the same way as during the pedagogical intervention, by institutions and by the categories stated above. Also, some interventions of the students in the focus groups supported the polls' results.

"What I know"

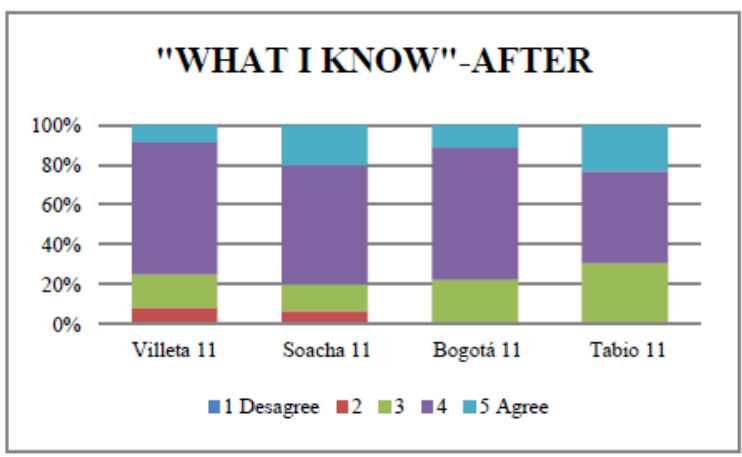

Figure 4. "What I know" after the pedagogical intervention

Students talk about the concept they have of the technology after the pedagogical intervention.

E4: ""Before the technology was a computer and all that. Now it is a tool that that helps you, with technology you can do several things to learn more things" (Student, last focus group).

"What I think"

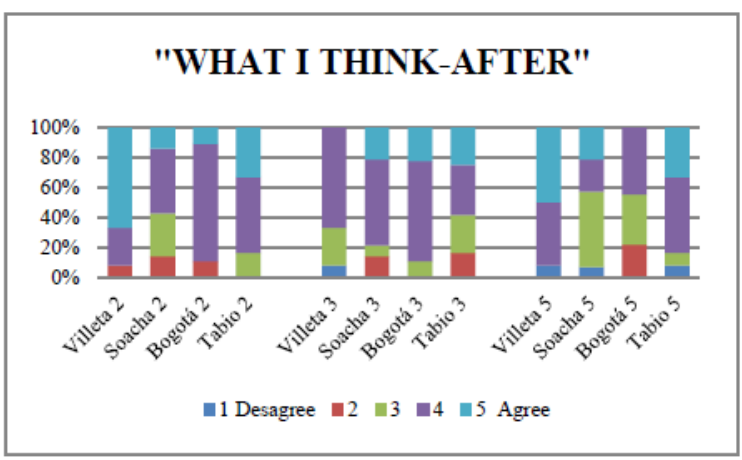

Figure 5. "What I think" after the pedagogical intervention

It is possible to said that I students can summarize their learning in problem solving and teamwork.

E1: "I liked solving problems here in Bagazal community" (Student, last focus group).

E3: "Yes of course. Because I learned two things: to implement, to look at the problems of the community and to seek effective solutions and efficient teamwork"(Student, last focus group).

"What I feel"

Students talked about
"Last year we put an activity and we need to make, however this year we had to find the problem and we had to fix it." (Student, last focus group).

Teachers' focus group

"What I know"

Teachers talked about their conception of technology.

T3: "The technology is the solution to problems, using different tools depends on your knowledge or weaknesses, but you can apply to different things, depending on what you need" (Teacher, last focus group).

"What I think"

Teachers also mentioned they had learned a lot in their technology class.

T1: "Yes, I learned a lot, especially the projectbased learning, we used the ABP with the fishtail, the problems tree, the feasibility matrix and here I have the results" (Teacher, last focus group).

"What I feel"

Finally teachers talked about the changes in their methodology with the pedagogical intervention.

T2: "Yes, because in my case I used guidelines and I had a sequence in the evaluation and the daily students' process. Instead the projects required to leave all year to seeing the fruits" (Teacher, last focus group).

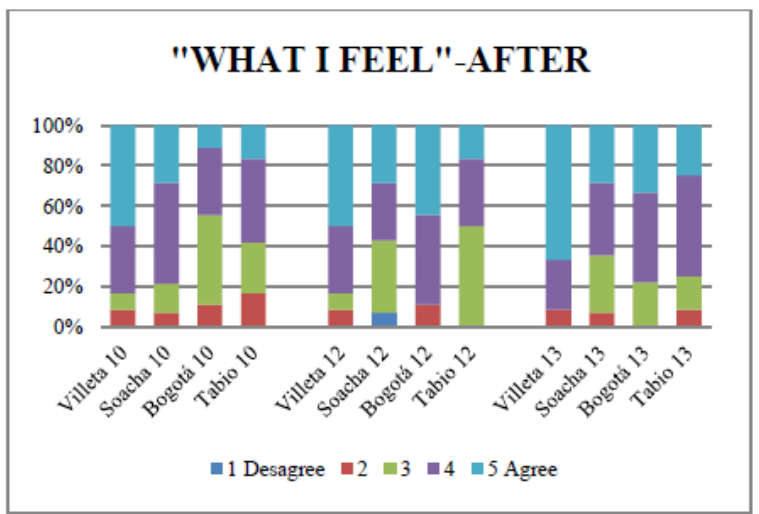

Figure 6. "What I feel" after the pedagogical intervention

\section{Conclusion}

As a conclusion, the proposal made from the CIER Center included the appropriation and use of new elements to the area of technology in which were strengthened the competences of the Guide Series No. 30. Doing the fieldwork, students noted as a positive aspect, of the pedagogical intervention, the use of new technological tools that allow them to expand their knowledge and spectrum use. They include, for example, the use of internet, because they learn to be users of the network and also takes advantage of the computers available at school, because they does not have at home. In a country like ours, where the access to education is limited, this is 
a fundamental aspect in pedagogical interventions, government agencies should be aware that not all Colombian students have possibilities of access to technology in their households and therefore educational institutions must fill those gaps in order to reduce the digital divide between those with access to technology and those do not.

Students in tenth and eleventh grades showed a high interest in the technology class that should be increased through appropriate teaching strategies.

It would be desirable to train teachers in the Guide Series No. 30 use. Also, further assistance from the government is needed, in terms of infrastructure and social factors associated with education. This, in order to provide more facilities for the proper development and exploitation of the technology implementation as a knowledge area in the country.

Regarding methodology, most teachers agree that the activities in the classroom and methodology are essential to encourage participation and work by students. Therefore they consider these kind of educational interventions are novel for several reasons: the teamwork, the activities proposed, problems solving, interdisciplinarity, among others. In accordance with what students talked, it can be said that the methodology of Project-Based Learning had great success and allowed teachers to make a change in their teaching practice possibly on future this rewarding gratifying results in Technology and informatics area in Colombia. The suggestion here would be that the implementation of this methodology and these pedagogical interventions not limited to these four institutions or teachers with who was worked the pedagogical intervention, but that would be a propagator action throughout the country.

It is necessary that the Ministry of Education implement educational interventions in the area of technology that covering various areas, from teacher training, to the provision of technological equipment adequate to the context, through a process of accompaniments in educational institutions in the country. In addition such interventions must be evaluated from two perspectives: one must take into account the extent of the achievements of these programs in terms of technological advances and on the other, as to the opinion of those who are part of the interventions. This in order to have an overall evaluation to propose possible improvements to the evidenced shortcomings and continue implementing what is working properly.

Regarding the perceptions, this work can be a model for understanding the social representations of teachers and students involved in educational interventions raised by the Ministry of National Education, seeking to develop skills in the area of technology and informatics.

\section{References}

[1] Ministerio de Educación Regional República de Colombia (2008). Serie Guía No. 30 Orientaciones generales para la educación en tecnología. Ser competente en tecnología:;Una necesidad para el desarrollo!http://www.mineducacion.gov.co/1621/articles160915_archivo_pdf.pdf (Acces date: 15 March 2015).

[2] Molina R., (2009). Hipótesis de progresión de las concepciones de los niños sobre el concepto de tecnología. Universidad Distrital Francisco José de Caldas.

[3] Rasinen, A., (2003). An Analysis of the Technology Education Curriculum of Six Countries. Journal of Technology Education Vol. 15 No. 1.

[4] The World Council of Associations for Technology Education (WOCATE) (2003). Technology Education Guide. Division of Secondary, Technical and Vocational Education Section for Science and Technology Education, UNESCO.

[5] Williams J., (2012) Technology Education for Teachers. International Technology Educations Series. Sense Publishers.

[6] Red Latinoamericana de Portales Educativos (RELPE) (2010). Experiencias Exitosas de Trabajo Colaborativo. Oficina Regional en Buenos Aires.

[7] Corporación Colombia Digital CCD (2013). TIC, educación y sociedad. Reflexiones y estudios de casos a nivel iberoamericano. Volumen 2. Universidad del Norte. Bogotá D.C. Colombia.

[8] Moscovici, S., (1985). Psicología social I. Ediciones Paidós. Impreso en España.

[9] Araya Umaña, S., (2002). Las representaciones sociales: Ejes teóricos para su discusión. Cuaderno de Ciencias Sociales No. 127 p. 1-79. Facultad Latinoamericana de Ciencias Sociales (FLACSO). Sede Académica, Costa Rica.

[10] Banchs, M., (2000). Aproximaciones procesuales y estructurales al estudio de las representaciones sociales. Papers on Social Representation. Threads of discussion. Peer Reviewed Online Journal Vol. 9. ISSN 1021-5573. Consultado: febrero 15 de 2015 en: http://www.psr.jku.at/PSR2000/9_3Banch.pdf

[11] Cohen L., Manion L. y Morrison K., (2007). Research Methods in Education. Rotledge. Sixth edition. London and New York.

[12] Abric, J., (2001). Prácticas Sociales y Representaciones. Ediciones Coyoacán, S. A. de C. V. Propiedad de esta edición (incluida la traducción).

[13] Coulon, Alain (1988). La etnometodología. Ediciones Catedra, Colección Teorema. Madrid.

[14] Hernández Sampieri, R., Fernández Collado, C. \& Baptista Lucio, M., (2010). Metodología de la 
Literacy Information and Computer Education Journal (LICEJ), Volume 7, Issue 3, September 2016

investigación. McGraw-Hill / Interamericana Editores,

S.A. Impreso en México. 